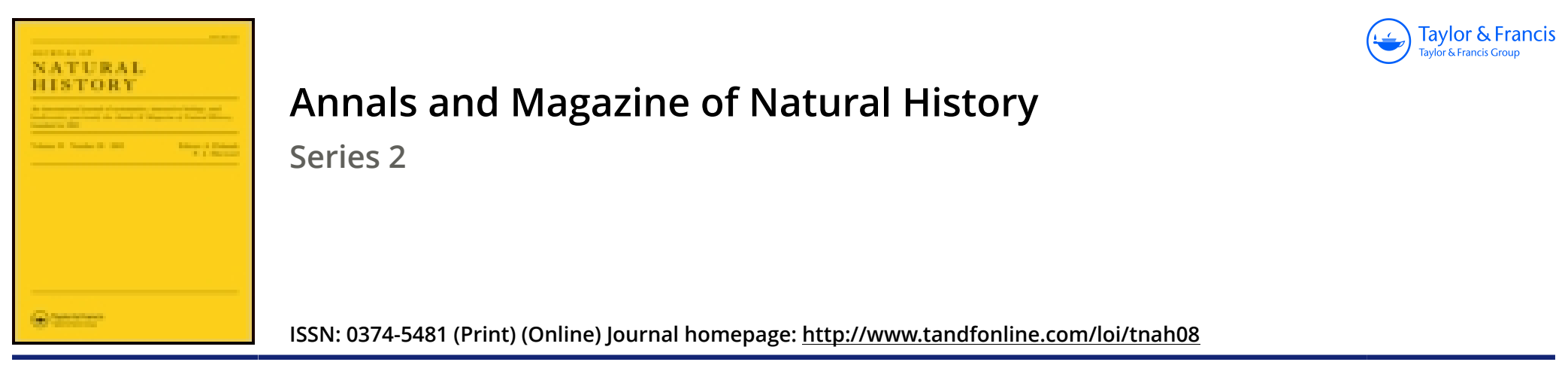

\title{
XXI.-Contributions to the botany of South America
}

\author{
John Miers Esq. F.R.S. F.L.S.
}

To cite this article: John Miers Esq. F.R.S. F.L.S. (1849) XXI.—Contributions to the botany of South America, Annals and Magazine of Natural History, 4:21, 185-193, DOI: $10.1080 / 03745486009494812$

To link to this article: http://dx.doi.org/10.1080/03745486009494812

曲 Published online: 17 Dec 2009.

Submit your article to this journal $₫$

Q View related articles $\asymp$ 
XXI.-Contributions to the Botany of South America.

By John Miers, Esq., F.R.S., F.L.S.

[Continued from p. 142.]

Marckea.

Or this genus no further information has hitherto been recorded beyond the short account first published by Richard, and so little has its affinity been understood, that it was considered by Endlicher as related to the Nicotianea. Its alliance however is evidently with Solandra and Juanulloa, agreeing with the Iatter genus in the structure of its calyx and fruit, and differing in the hypocrateriform shape of its corolla, with broad, expanded and almost rotate border, and in its scarlet colour.

From a plant in Sir William Hooker's herbarium, with only a single flower and fruit, I have been able to make the following analysis, which in some respects is incomplete, as I was anxious not to injure the specimen.

Marckea, L. C. Richard. Lamarckea, Pers.-Calyx 5-sepalus, persistens, vix augescens : sepala lanceolata, acuminatissima, imo angustata, primum ultra medium, marginibus ciliatis, in tubum pentagonum valvatim conniventia, hinc superne lineariattenuata, erecta, libera, dein in fructu omnino sejuneta. $\mathrm{Co}$ rolla hypocrateriformis, tubo elongato, cylindrico, fauce subinflato, limbo 5-partito, laciniis oblongis, rotundatis, rotatoexpansis, subreflexis, æstivatione imbricata. Stamina 5, æqualia, paulo supra basin corollæ orta, basi lanata, filamenta erecta, tenuia, anthere in faucem corollæ inclusæ, 2-loculares, linearioblongæ, lobis disjunctis, puncto medio affixis, rima marginali longitudinaliter dehiscentibus. Ovarium 2-loculare, placentis e dissepimento utrinque cruciatim tenuiter partientibus, hinc incrassatis undique ovuligeris, ovulis angulo basali nexis, adscendentibus. Stylus tenuis, longitudine staminum. Stigma integrum? Bacca fere capsularis, exsucca, evalvis, pericarpio tenui indehiscente, sepalis persistentibus tecta, oblonga, 2-sulcata, 2-locularis. Semina plurima, imbricatim disposita, oblonga, acuminata, imo gibba, hilo in angulo basali, adscendentia, testa laxa. Embryo intra albumen parcum, carnosum, axillaris, leviter arcuatus, radicula infera tereti, cotyledonibus ovatis, compressis, incumbentibus, æquilonga.-Suffrutices Guianenses et Antillani scandentes, ramis dependentibus; folia alterna, petiolata, elliptica, acuta, integra, glabra ; racemi axillares ; corolla coccinea.

1. Marckea coccinea, L. C. Rich. Act. Soc. Hist. Nat. Par. 107; A. Rich. Dict. Class. x. 168. cum icone. Lamarckea coccinea, 
Pers. Ench. i. 218 ;-scandens, glaberrima ; foliis oblongis, apice subito acuminatis, imo obtusis, nitidis, subcoriaceis; racemo longe pedunculato, paucifloro, corolla coccinea, calyce 2-3-plove longiore.-Guiana, v. s. in herb. Hook. (Surinam, Hostman, no. 348).

This is evidently a scandent plant with slender branches; the leaves are about $7 \frac{1}{2}$ inches long, $2 \frac{3}{4}$ inches broad, upon a somewhat slender petiole, somewhat thickened at base, $\frac{1}{2}$ inch in length ; they are quite smooth and of thick texture; the peduncle of the raceme is axillary, about $3 \frac{1}{2}$ inches long, bearing a few flowers, only one remaining in the specimen above referred to; the pedicel is about $I$ inch in length ; the sepals are $1 \frac{1}{4}$ inch long, scarcely 3 lines broad in the middle; the tube of the corolla is $1 \frac{3}{4}$ inch long, 2 lines in diameter, swelling to half an inch below the mouth; the lobes are 5 lines long, 4 lines broad, rounded, veined, overlapping each other on their margins, and when expanded, form a border about $1 \frac{1}{4}$ inch in diameter ; the insertion of the stamens is about half an inch above the base of the tube, the filaments are very slender, nearly an inch long, and the anthers are 3 lines in length; the berry is 8 lines long, 4 lines in diameter, apparently quite free of pulp, with a thin pericarp and slender dissepiment, containing numerous divaricate, ascending, imbricate seeds, each about $1 \frac{1}{2}$ line in length*.

2. Marckea ? longiflora (n. sp.);-scandens, ramulis glabris compressis ; foliis alternis, oblongis, apice repente acuminulatis, e medio ad basin subattenuatis, breviter petiolatis, coriaceis, glaberrimis, opacis; racemo sub-brevi, paucifloro ; corolla calyce 4-5-plo longiore, tubo supra medium cylindraceo-campanulato, limbi laciniis ovatis, subreflexis, staminibus inclusis.-Trinidad, v. s. in herb. Hook. (La Laguna de Ora pouche, Purdie.) This plant corresponds in its habit with Marckea, but the specimen above referred to presents only a single flower in a very bad condition, so that it is impossible to determine with certainty whether or not it belongs to this genus. The leaves are $7_{4}^{1}$ inches long, $3 \frac{3}{4}$ inches broad, on a somewhat slender petiole thickened at base, and half an inch in length ; they are quite coriaceous, opake but not polished, though entirely glabrous; they are marked with strong prominent nerves; the peduncle of the raceme is apparently about $1 \frac{1}{2}$ inch long, the pedicel 8 lines; the calyx exactly corresponds with that of the preceding species, the sepals being nearly an inch long, including their suddenly contracted linear apical points of 3 lines; they are about 4 lines broad, with nearly

* A representation of this plant, with sectional details, will be given in the 'Illust. South Amer. Plants,' plate 45. 
parallel margins, which are slightly connivent; the tube of the corolla is about 3 inches in length, contracted at base for the length of $1 \frac{1}{4}$ inch to scarcely more than $1 \frac{1}{2}$ line broad, and swelling above to a diameter of half an inch; the lobes of the border are about half an inch in length and 4 or 5 lines in breadth, somewhat obtuse and patent; the stamens appear to originate in the contraction of the tube, with the anthers considerably below the mouth of the border; the corolla is of much thinner texture than that of $M$. coccinea : in the form of its berry and enveloping calyx, the arrangement, size, and shape of its seeds, its lax testa, very thin albumen, and form of its embryo, it quite agrees with the former species.

\section{JuANULLOA.}

This little-known genus of the 'Flora Peruviana' was scarcely understood by the botanists of our time, until the very interesting. account and excellent figure of a plant raised from seed in the Botanic Gardens of Kew was lately published by Sir Wm. Hooker. This proves to be a very different species from that figured by Ruiz and Pavon, and although generically identical with the Laureria mexicana of Schlechtendal, is again specifically distinct from it. The genus approaches Solandra in its climbing habit, large coriaceous leaves, and in the general structure of its flower and fruit, agreeing with it also in having a calyx consisting of five distinct sepals, conniving by their edges into an acutely pentangular tube, but here they subsequently become quite separate; it is also dissimilar in the cylindrical form of its corolla, with a small border of five rounded patent lobes, and with included stamens. It likewise approaches Marckea in the structure of its calyx, in which respect it resembles Nicandra and Cliocarpus, with which latter genus it also agrees, in having stellate tomentum. I have been able to complete from different sources the following amended generic character :-

Juanulloa, R. \& P. Prodr. xxvii. tab. 4. Ulloa, Pers. Ench. i. 218. Laureria, Schlecht. Linn. viii. 513. Brugmansia, Sp. hortul.-Calyx coloratus, 5-sepalus, sepalis oblongo-acutis, marginibus subreflexis undulatis valvatim conniventibus, tubum inflatum 5-angularem ore coarctatum et 5 -dentatum simulantibus, dein liberis et persistentibus. Corolla cylindricotubulosa, medio inflata, carnosula, fauce coarctata, limbo 5-lobo, lobis brevissimis, rotundatis, patentibus, æstivatione imbricata. Stamina 5, aqualia, inclusa, erecta, flamenta in coarctationem imam corollæ inserta, basi villosa, anthera sublineares, 2-lobæ, lobis parallelis, connectivo lineari dorsali adnatis, intus longitudinaliter dehiscentibus. Ovarium conicum, disco carnoso 5lobo impositum, 2-loculare, multiovulatum, placentis centra- 
libus incrassatis dissepimento utrinque adnatis. Stylus inclusus, apice crassescens. Stigma oblongum, sub bilabiatum, lobis earnosis, adpressis, intus glandulosis. Bacca ovata, sepailis sejunctis cincta, 2-locularis. Semina plurima in pulpam. nidulantia, oblonga, vix reniformia, compressa, hilo infra medium laterali. Embryo intra albumen carnosum, fere rectus, radicula infera, tereti, paulo incurvata, cotyledonibus oblongis, crassis, compressis, accumbentibus, rectis, duplo longiore.Suffrutices Peruviani et Mexicani dependentes; folia alterna, oblonga, integra, coriacea, pube tomentosa stellata plus minusve induta ; racemi terminales penduli; flores aurantiaci, vel punicei.

1. Juanulloa parasitica, R. \& P. Fl. Peruv. ii. 47. tab. 185. Ulloa parasitica, Pers. Ench. i. 218;-suffrutex epiphytica, ramulis junioribus angulatis, glabris, epidermide tenui rimosa ; foliis oblongis, acuminatis, coriaceis, nitidis, ruguloso-punctulatis, subtus albido vel flavido-furfuraceis, petiolo canaliculato, tenui, Iimbo 4-6-plo breviore; racemis terminalibus, pendulis, dichotome ramosis; calyce magno, ovato, carnoso, colorato, inflato, 5-angulato, laciniis demum sejunctis ; corolla punicea, cylindrica, calyce paulo longiore, medio subinflata, fauce coarctata, lobis brevibus rotundatis, patentibus; bacca cerasi magnitudine punicea, sepalis erectis vestita.-In Andibus Peruvianis excelsis, Pozuzo, Prov. Tarmæ, v. s. in herb. Mus. Brit. (Pavon).

The leaves in this species are $5 \frac{1}{2}$ inches long, $2 \frac{1}{2}$ inches broad, with a thick channeled petiole of $\frac{3}{4}$ inch in length; the raceme is paniculate, 4-5 inches long, the pedicels $\frac{1}{2}$ inch; the calyx, almost glabrous, is $1 \frac{1}{2}$ inch long, and $\frac{3}{4}$ inch diameter; the corolla is $1 \frac{3}{4}$ inch long, 4 lines in diameter in the middle, 3 lines at both extremities, the lobes of the border being scarcely 2 lines in size; the filaments are 5 lines long, the anthers of equal length, the berry being 1 inch long and $\frac{3}{4}$ inch in diameter.

2. Juanulloa Mexicana. Laureria Mexicana, Schlecht. Linn. viii. 513. Brugmansia floribunda?, Paston, Mag. Bot. ix. 241. cum icone;-frutex orgyalis, ramis glabris, epidermide rimosa, junioribus fulvido-tomentosis ; foliis ovatis, v. lato-lanceolatis, utrinque breviter acutis, supra lævibus, subtus præsertim in nervis tomento molli stellato tectis, breviter petiolatis ; calyce magno, e sepalis 5, lato-ovatis, imo anguste attenuatis, tertia parte infimo in tubum 5-gonum 5-alatum margine cohærentibus, demum sejunctis; corolla calyce paulo longiore, tubulosa, sub-5-gona, extus stellato-tomentosa, intus glabra, carnosa, limbi laciniis brevibus, obtusis : staminibus imo tomentosis, inclusis.-Mexico, La Laguna (Schiede); v. s. in herb, Hook. (Tenampa, Prov. Vera Cruz, Linden, no. 50). 
The leaves of this plant are described by Schlechtendal as being from 4 to 6 inches long and from 2 to 3 inches broad, upon a very short petiole of only 3 or 6 lines in length; the calyx is $1 \frac{1}{4}$ inch long, increasing to $1 \frac{1}{2}$ inch; the corolla is $I \frac{1}{2}$ inch long; the filaments being 9 lines and the anthers 5 lines in length.

Linden's plant above quoted, I have presumed to be the same species : here the leaves are thick and coriaceous, quite smooth above, clothed below with yellowish stellate down; they are broadly ovate, shortly and suddenly attenuated at the obtuse emarginated apex, $5 \frac{1}{2}$ inches long, $3 \frac{1}{2}$ inches broad, on a thick channeled petiole of $\frac{5}{8}$ to $\frac{3}{4}$ inch in length ; the inflorescence is much longer than in any other species, each dichotomous branch forming a distinct raceme of $4 \frac{1}{2}$ inches in length, bearing the articulations of several flowers towards their apex, which have all fallen off.

3. Juanulloa Hookeriana. Juanulloa parasitica, Hook. Bot. Mag. tab. 4118 ; -frutex subscandens, ramis glabris, incano-glaucis epidermide rimosa, junioribus argenteo-tomentosis : foliis elliptico-oblongis, utrinque subattenuatis, subcoriaceis, supra lævibus, subtus alutaceo-pulverulentis, pilis stellatis subtomentosis, petiolo glabro, subtenui, canaliculato; racemo brevi, subpaniculato, terminali, pedicellis brevissimis, crassis ; calyce magno, inflato, 5-angulato, breviter 5-dentato, angulis mox alatis et undulatis, e sepalis lineari-lanceolatis, 3-nerviis, crassocoriaceis, aurantiaco-pulverulentis, margine cohærentibus, demum liberis et persistentibus; corolla cylindracea, imo breviter coarctata, calyce tertio longiore, limbi laciniis ovatis, obtusis, patentibus ; antheris infra faucem arcte conniventibus.-Patria ignota; $v$. v. cult. in hort. Kew.

The leaves of this species are $5 \frac{1}{2}$ inches long, $2 \frac{1}{2}$ inches broad, on a petiole of $\frac{1}{2}$ to $\frac{3}{4}$ inch in length ; the terminal inflorescence branches into two or three very short few-flowered racemes, the pedicels being 2 lines in length; the thick fleshy sepals are of an orange colour, $1 \frac{1}{4}$ to $1 \frac{3}{8}$ inch long, $\frac{3}{8}$ inch broad, forming by their connivent edges a long and somewhat ventricose pentangular tube, the angles appearing in some degree winged and undulating; the tube of the corolla is $1 \frac{3}{4}$ inch long, 4 lines in diameter, very thick and fleshy, of a deep orange colour, externally clothed with fine floccose down, and smooth within, the segments of the border being rounded, barely 3 lines long, and $2 \frac{1}{2}$ lines broad; the stamens are fixed in the contracted portion of the tube, 3 lines above the base, and are pilose at their origin, quite smooth and terete above, erect, 11 lines long; the anthers, with somewhat mucronate apex, are 4 lines long, 1 line broad, adnate to a linear dorsal connective continuous with the flament; the ovarium is conical, seated upon a thick fleshy five-lobed gland, with emar- 
ginated rounded lobes; the style is erect, smooth, thickened and hollow towards the summit; the stigma consists of two oblong, adpressed, semiterete fleshy lobes, lined inside with green viscous glands.

4. Juanulloa Panamensis (n. sp.);-frutex subscandens, ramis glabris, anguloso-compressis, epidermide rimosa ; foliis elliptico-oblongis, utrinque attenuatis, coriaceis, supra lævibus, subtus alutaceo-pulverulentis, pilis stellatis flavidis tomentosis, petiolo glabro, subtenui, canaliculato; racemis brevissimis, 3-4, terminalibus, aggregatis, floribus sub-umbellatim confertis : pedicellis calyce fere æquilongis, demum in fructu apice incrassatis duplo longioribus ; calyce breviore pseudo-angulato, sepalis demum liberis, lanceolatis, acutis, basi latis, carnosis, aurantiaco-pulverulentis ; corolla cylindracea, imo oreque coarctata, supra medium inflata, calyce fere 3-plo longiore, nervis 5 prominentibus, limbi laciniis brevissimis, obtusiusculis, staminibus inclusis; bacca oblonga, stylo persistente apiculata, sepalis coriaceis sejunctis cincta.-Panama, v. s. in herb. Hook. Veraguas (Seemann, no. 1200).

This species bears much resemblance in the form and size of its leaves to $J$. Hookeriana, but its inflorescence is very different, its calyx not half the size, the sepals less acuminate, the corolla longer and more contracted in its lower half. The leaves are 5 inches long, $2 \frac{1}{2}$ inches broad, on a petiole $\frac{1}{2}$ to $\frac{3}{4}$ inch in length ; they have a silvery lustre beneath, although covered somewhat more sparsely with yellow stellate or rather brachiate tomentum. The racemes, almost fasciculate at the apex of the branch, are scarcely more than $\frac{3}{8}$ of an inch in length; the pedicels are $\frac{1}{2}$ inch long in flower, 1 inch long in fruit; the sepals are little more than $\frac{5}{8}$ inch long and $\frac{3}{8}$ inch broad at base, and do not increase in size, but remain erect, separated, coriaceous, and embracing the ovate berry, $\frac{3}{4}$ inch long, $\frac{5}{8}$ inch diameter, crowned by the long, slender, persistent style; the seeds are 2 lines long, nearly a line in breadth, and they have afforded the structural features given in the generic character*.

\section{SARCOPHYSA.}

Among the plants collected by Goudot and Purdie in New Granada, is one that nearly approaches Solandra, Juanulloa and Marckea, not only in its scandent habit, with large coriaceous leaves, but in the form of its corolla. It differs however from those genera in having a large, ovate, fleshy, tubular calyx, which

* A representation of this species with sectional details, and an analysis of the flower of $J$. Hookeriana, will be shown in plate 46 of the 'Illustr. South Amer. Plants.' 
is much inflated in the middle, with a remarkably contracted mouth, bursting irregularly with the growth of the fruit, and not divided into distinct sepals as in the other genera above-mentioned; it is also distinguishable from Juanulloa by its long, handsome, tubular corolla. Its name is derived from $\sigma \grave{c} \rho \xi$, caro, and $\phi \dot{v} \sigma \eta$, vesica, because of its fleshy inflated calyx.

SARCoPhYSA (gen. nov.).-Calyx magnus, coloratus, ovatus, inflato-tubulosus, crasso-carnosus, ore coarctato, breviter 5-partito, laciniis acutis, erectis, persistens, sed non augescens. Corolla cylindrico-tubulosa, tubo medio subinflato, calyce 3-plo longiore, limbo breviter 5 -lobo, lobis acutis reflexis, staminibus styloque inclusis. Bacca ovata, styli basi apiculata, calyce coriaceo irregulariter fisso vestita. Cætera ignota.-Suffrutex scandens Nove Granade, folia alterna, ovata, coriacea; racemi penduli, pauciflores; corolla speciosa.

1. Sarcophysa speciosa (n. sp.);-ramis dependentibus, dense tomentosis ; foliis ovatis, basi obtusis, apice breviter angustatis, crasso-coriaceis, nervis profunde impressis, supra glaberrimis, minute ruguloso-punctulatis, subtus flavido-tomentosis, pilis stellato-brachiatis, petiolo crasso, reflexo, canaliculato, subbrevi; calyce magno, colorato ; corolla punicea?, calyce duplo longiore, extus subtomentosa ; bacca magna, calyce vix aucto, fisso, æquilongo, inclusa.-Nova Granada, v. s. in herb. Hook. (Quindiu et Palmas, Goudot; Quindiu, Purdie).

This appears to be a scandent plant; its leaves are quite smooth above, with a finely rugulose or shagreened surface; below they are, as well as the petiole, covered with a dense orange-coloured and short tomentum; they are 4 inches long, $2 \frac{1}{2}$ inches broad, on a thick channeled petiole half an inch long; the flowers appear racemose; the calyx $1 \frac{1}{2}$ inch long, nearly an inch in diameter; the corolla is $2 \frac{1}{2}$ inches in length, 8 lines diameter in the middle, contracted at both extremities to 5 lines, with oblong triangular teeth, 3 lines long; the berry unripe is $1_{4}^{1}$ inch long, $\frac{3}{4}$ inch diameter, surrounded by the persistent coriaceous calyx, which is irregularly split on one side to the base; the hairs of the tomentum are distinctly brachiate*.

\section{Ectozoma.}

In the Pavonian herbarium, preserved in the British Museum, I have noticed a plant that offers much analogy with the foregoing genera, agreeing with all the Solandree in its habit, its coriaceous leaves, and terminal paniculated inflorescence, and

* This species will be shown in plate 47 of the 'Illustr. South Amer. Plants.' 
although its flowers are much smaller, they agree in having a fleshy tubular corolla with five short lobes, which are imbricated in estivation. They present the unusual character of the insertion of the stamens upon a free perigynous ring, as in Triguera, but with the peculiarity of being adnate upon its external face; hence

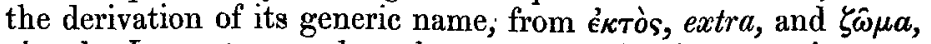
cingula. In most cases where the stamens spring from a perigynous ring, the filaments originate from its inner face, as in Salpichroma, or from its margin, as in Triguera ; but we have a somewhat analogous case in Campanula medium, where the filaments are distinctly adnate upon the back of the large, broad processes, that form the fornix around the base of the style, peculiar to that genus. Its generic features may be characterized as follows :-

Ecrozoma (gen. nov.).-Calyx campanulatus, brevis, crassus, subæqualiter 5-dentatus, dentibus triangularibus, eréctis. Corolla breviter tubulosa, medio subinflata, crasso-carnosa, limbo 5lobo, lobis suborbicularibus, æstivatione imbricatis. Stamina 5 , xqualia, inclusa, filamenta brevissima, compressa, e dorso annuli perigyni liberi tenuis margine ciliati orta. Anthere oblongæ, imo subcordatæ, apice nucronulatæ, lobis coriaceis connectivo dorsali lineari parallele adnatis, margine longitudinaliter dehiscentibus. Ovarium obovatum. Stylus erectus. Stigma fere exsertum, globosum, sub-2-lobum. Fructus ignotus.Suffrutex Ecuadorensis, glaberrimus, subscandens?; folia alterna, ovata, vix acuta ; inflorescentia paniculata, terminalis.

1. Ectozoma Pavonii ;-glaberrima, ramulis compressis, subangulatis, epidermide rimosa ; foliis late ovatis, basi apiceque obtusiusculis, vix acutis, crasso-coriaceis, supra impresso-punctulatis, venis insculptis, subtus pallidis, venis prominentibus, petiolo crasso canaliculato ; racemis paniculatis, 2-3, terminalibus; floribus breviter pedicellatis, calyce carnoso aurantiaco, piloso, pilis brevibus articulatis ; corolla carnosa, aurantiaca, glabra, limbi laciniis crassiusculis.-Guayaquil, $v$. s. in herb. Mus. Brit. (Pavon).

This plant bears much resemblance in its habit to Juanulloa and Sarcophysa. Its branchlets are much compressed, covered with a shining peeling bark; the leaves are 5 inches long, $3 \frac{1}{2}$ inches broad, on a thick channeled petiole of half an inch in length. Its paniculate branching raceme is about 2 inches long, each pedicel is 1 line long; the calyx, 4 lines in length and 3 lines in diameter, is very fleshy and rugosely pilose, and is divided to one-third its length into five equal erect teeth; the tube of the corolla is 3 lines long, and the circular lobes of its border 1 line in diameter, the tube is somewhat narrowed at its base and in the throat; the antheriferous free ring arises in the constriction of 
the tube. It is possible that in the specimen referred to, the flowers are only in a young state, and that when fully grown they may assume a somewhat greater development, but I give the description in accordance with the specimen as it exists*.

XXII.-Characters of Diplommatina, a new genus of Terrestrial Mollusks belonging to the Family of Carychiadæ, and of a second species contained in it; also of a new species of Carychium inhabiting the Western Himalaya. By W. H. Benson, Esq.

A $\mathrm{T}$ page 81, vol. ii. of Pfeiffer's excellent Monograph of the Helicide, there appears an erroneous reference to that family of an anomalous shell, the animal of which must exclude it from the position there assigned to it; - I allude to the little Himalayan species called by Capt. Hutton in MSS. Carychium costutum, which Dr. Pfeiffer has described under the title of Bulimus folliculus. Capt. Hutton, referring to the situation of the eyes and to their not being borne on the summits of the tentacula, associated the form with Carychium. The shell alone, differing in the shape of the aperture and destitute of plaits or teeth, would certainly be anomalous in that genus; but it formed the only published type to which the species could be approximated. The following is the recorded result of my own repeated observations of the animals of both species.

Tentacula two only, originating from the upper part of the head, long and filiform; eyes situated on the posterior part of the tentacula at their base, composed of two lobes : one lobe deeply seated in the tentaculum and larger than the other lobe, which is a small black point coming to the surface on the outer side of the larger lobe; foot short.

Had the animal been provided with an operculum $\dagger$, it might possibly have been referred to the family of Cyclostomatidæ in accordance with the position of the eyes, and the form of the aperture of the shell. The differences observable in the latter, as well as in its inhabitant, give countenance to a separation from Carychium; I therefore propose for the type the following name derived from the peculiarity of the percipient points or eyes.

\section{Diplommatina, nobis.}

Char. Gen. Testa vix rimata, tenui, subovata; spira elongata; anfractibus convexis, costatis, ultimo subascendente ; apertura eden-

* A representation of this plant with details will be shown in plate 48 of the 'Illustr. South Amer. Plants.'

+ I believe I have the concurrence of the major part of the conchologists of the present day in dissenting from Rang's opinion, "qu'il n'est pas possible d'établir des divisions fondées sur la présence ou l'absence d'opercule. "Vide Rang's Manuel, p. 198, Art. Litiopa.

Ann. Mag. N. Hist. Ser. 2. Vol. ir. 